\title{
A REVIEW OF FERTILISER TRIALS IN TUVALU AND KIRIBATI
}

by

\author{
K. TREWREN ${ }^{1}$
}

\begin{abstract}
A brief introduction is given to a programme of 34 fertiliser trials (possibly the largest programme of fertiliser trials in the world) that have been carried out in Tuvalu and Kiribati. Some of the more striking results that have emerged have been presented, and it is hoped that readers who would find more detailed information for use to them will ask for the relevant reports from the Department of Agriculture of the two countries concerned.

The majority of the trials were conducted within the 1978 and 1993 period, being started by Trewren, and the longer running trials in Kiribati were continued by Edwards and, in most cases to their conclusion, by Barr.

The results obtained have made it possible to formulate with some confidence recommendations on the manuring of coconuts on atolls, from seedlings in the nursery to mature palms in the field, including the rehabilitation of palms suffering from very severe deficiencies of trace elements and potassium. From foliar analysis, much useful information has been obtained on the inter-relationships between nutrients, and in particular, on the fundamental importance of iron and other trace elements on the assimilation of macro-nutrients and on the need to maintain a correct balance amongst trace elements.
\end{abstract}

Further research is needed to identify a suitable source of nitrogen. Less important topics for research could be investigations into the optimum quantity of potassium chloride application to nursery seedlings and the optimum frequency of application of potassium chloride in the field.

\section{INTRODUCTION}

Kiribati and Tuvalu are atoll countries, situated in the central and south Pacific. Coconuts are of fundamental importance to both countries, being the major source of foreign exchange (as copra), and a major component of the subsistence diet, in various forms.

A coconut rehabilitation and replanting programme for smallholders was started in 1970 (funded by U. K. Government), following on from a number of observation plots that had been planted in the 1960's. At that time Kiribati and Tuvalu were combined as the Gilbert and Ellice Islands Colony. Results from the replanting programme were disappointing, and further replanting was halted in 1981.

Between 1979 and 1981 nine fertilizer trials were started by Trewren in Tuvalu, and four trials on seedlings in the nursery were carried out between 1984 and 1986. During this latter period a further thirteen trials were started in Kiribati, whilst all except two of the trials in Tuvalu were phased out. After Trewren's departure in 1987 the work was continued by Edwards and latterly by Barr. In addition to these 26 trials, six trials on trace elements and two nonstatistical observation plots on micronutrients had been carried out on Kiritimati (Christmas Island, Kiribati) between 1963 and 1977.

\footnotetext{
${ }^{1}$ Consultant Tropical Tree Crops
} 
In the first trials to be laid down, treatments were based on results obtained from earlier work carried out in French Polynesia by Fremond, Pomier, Manciot and others (Fremond 1958, 1961; Pomier 1964, 1967/a, 1967/b, 1969; Manciot 1967). The work carried out in French Polynesia has been described more recently by Reboul (Reboul 1980, 1982). The early trials on Kiritimati ran concurrently with those in French Polynesia and drew upon the expertise available from that source. The technique of trunk injection of coconuts that was used in several trials had previously been used in French Polynesia, and, using a drip-fed technique, by Meadows in Kiribati (Meadows 1961).

In 1982 Trewren carried out a survey of coconut plots in Kiribati which had been replanted by smallholders, the results of which established beyond doubt that the main reason for the disappointing results was a severe nutritional problem, with a number of elements being involved. The levels of no less than five elements (nitrogen, potassium, iron, manganese and zinc) were the lowest ever recorded in surviving palms. Lower levels of copper had previously been found only in Tuvalu (Trewren, 1993). The results of the survey formed the basis for the programme of fertiliser trials that was subsequently implemented in Kiribati.

Although the majority of the trials were nutritional, there have also been four systematic spacing trials in Kiribati. other aspects of coconut production were also investigated, including cover crops, intercropping, reduction of the population density, germplasm surveys and the production of millionaires, salad. These other investigations are beyond the scope of this review, but are included in respective Annual Technical Reports.

The fertiliser trials which formed the core of this programme are listed in Table 1, which gives the title and reference number of each trial, the site, period over which the trial was conducted, and the report in which results are presented in most detail.

In most years between 1979 and 1993 the results from each trial have been written up in Annual Technical Reports, but in a few instances such reports cover two or three years. A trial which ran for several years Is described in each of the reports written during those y9ars, but the most detailed summary of results is given in the report of the year in which the trial was concluded. Table 1 is therefore a concise guide for those who would like to have further information on some or all of these trials. Copies of the Annual Technical Reports are available from the Departments of Agriculture of the two countries.

Table 1. List of fertiliser trials and observations in Tuvalu and Kiribati

\begin{tabular}{lllll}
\hline $\begin{array}{c}\text { Experiment } \\
\text { reference } \\
\text { number }\end{array}$ & \multicolumn{1}{c}{ Title } & \multicolumn{1}{c}{$\begin{array}{c}\text { Island/1 } \\
\text { country }\end{array}$} & $\begin{array}{c}\text { Year } \\
\text { conducted }\end{array}$ & $\begin{array}{c}\text { Final } \\
\text { write-up }\end{array}$ \\
Macronutrient Trials & & & \\
E R 23 & Nitrogen, Potassium and Placement Trial & Vaitupu/T & $1981-87$ & 1987 \\
E R 24 & Potassiun Placement Trial & Vaitupu/T & $1981-87$ & 1987 \\
E R 5 & Basic Nutrition Trial, Temiku Bight & Tarawa/K & $1973-86$ & 1986 \\
E R 27 & N x P x K x 'X' FertiLiser Trial on Marginal Lard & Tarawa/K & $1984-93$ & $1990-92$ \\
E R 34 & N x P x K x 'X' x Fe Fertiliser Trial on 'Normal' Soil & Tarawa/K & $1990-92$ & $1990-92$ \\
& N x P x K x 'X' x Size of Planting Hole Trial using Seedlings & Tarawa/K & $1984-86$ & 1966 \\
E R 12 & Nitrogeneus Fertitiser Trial & Tarawa/K & $1971-74$ & $1982-84$ \\
E R 4 & Fertilizer Observation on Young Palms, Banam Village & Kiritimati/K & $1971-77$ & 1985 \\
E R 45 & Fertitiser Observation on Mature Palms & Kiritimati/K & $1972-73$ & 1985 \\
E R 40 & Hybrid Coconut Fertilizer Observation & Tarawa/K & 1986 & 1986 \\
\hline
\end{tabular}




\begin{tabular}{|c|c|c|c|c|}
\hline \multicolumn{5}{|c|}{ Micronutrient trials: } \\
\hline ER 2 & Trace Element Trial & Vaitupu/T & $1979-80$ & 1980 \\
\hline E R 14 & Trunk Injection Trial an Young Non-flowering Coconuts & Vaitupu/T & $1980-85$ & 1965 \\
\hline E R 15 & Trunk Injection Trial on Young Flowering Coconuts & Vaitupu/T & $1980-85$ & 1985 \\
\hline E R 20 & Levels of Iron Injection into Old Cocorut Trees & Vaitupu/T & $1960-85$ & 1985 \\
\hline E R 22 & Iron Injection Trial with Twelve Year Old Coconuts & Nukulaelae/T & $1981-86$ & 1966 \\
\hline E R 35 & Marganese, Zinc ard Copper Trial & Maiana/K & $1986-92$ & 1990-92 \\
\hline E R 36 & Trace Element Trial with Young Coconuts & Maiana/K & 1986-(95) & 1990-92 \\
\hline E R 37 & Levels of Trace Elements Trial & Maiana/K & $1986-91$ & 1990-92 \\
\hline E R 38 & Iron Application Trial & Maiana/K & $1986-91$ & 1990-92 \\
\hline $1 / 67$ & Trace Element Trial No.14 & Kiritimati/K & 1967-? & See note 4 \\
\hline $2 / 67$ & Trace Element Trial No. $2^{4}$ & Kiritimati/K & 1967-? & See note 4 \\
\hline $3 / 67$ & Trace Element Trial No. $3^{4}$ & Kiritimati/K & 1967-? & See note 4 \\
\hline $4 / 67$ & Trace Element Trial No. $4^{4}$ & Kiritimati/K & 1967-? & See note 4 \\
\hline- & Trace Elements ${ }^{4}$ & Kiritimati/K & 1963-? & See note 4 \\
\hline- & Trace Elements 4 & Kiritimati/K & 1965-? & See note 4 \\
\hline \multicolumn{5}{|c|}{ Nursery Trials: } \\
\hline E R 17 & Fertilizer Placement Trial on Coconut Seedlings & Vaitupu/T & $1980-82$ & 1982 \\
\hline E R 16(A) & Trace Element Trial on Cocorut Seedlirgs & Vaitupu/T & 1985 & 1985 \\
\hline E R 30 & Trace Element Trial on Cocorut Seedlings & Tarawa/K & 1986 & 1986 \\
\hline E R 67 & Trace Element Placement Trial to Cocorut Seedlings & Vaitupu/T & 1985 & 1985 \\
\hline E R 32 & Trace Element Placement Trial to Coconut Seedlings & Tarawa/K & 1986 & 1986 \\
\hline E R 68 & Levels of Trace Element Apptication to Coccrut Seedlings & Vaitupu/T & 1985 & 1985 \\
\hline E R 31 & Levels of Trace Element Applicaticn to Coccnut Seedlings & Tarawa/K & 1986 & 1986 \\
\hline- & Coconut Nursery Disease Control Trial & Vaitupu/T & $1986-87$ & 1987 \\
\hline \multicolumn{5}{|c|}{ Other trials: } \\
\hline E R 25 & $\begin{array}{l}\text { An Evaluation of Coconut Wood Ash as Fertilizer and } \\
\text { Coconut Charcoal to Improve the Moisture Retention of } \\
\text { Coralline Soil }\end{array}$ & Vaitupu/T & 1981 & 1981 \\
\hline
\end{tabular}

Notes:

1. In the column headed "Island/country", $\mathrm{T}=\mathrm{Tuvalu}, \mathrm{K}=$ Kiribati.

2. In the titles of the trials the words "on coconuts", or "with coconuts" have been omitted where they are superfluous for the purpose of this review.

3. manganese, zinc and copper trial included macronutrients in the treatments.

4. Six trials on trace elements were carried out on Kiritimati (Christmas Island) between 1963 and 1967. The trials started in 1963 and 1965 have been described by Jenkin and Foale (1968) but there is little or no information available on the subsequent fate of these trials and those started by Cook in 1967.See also Trewren (1965). 


\section{METHODOLOGY}

Except where the word observation has been used in the title, all of the trials carried out were sufficiently replicated to permit of statistical analysis. However the nitrogenous Fertilizer trial (E R 12) could not be analysed due to flawed design.

Nearly all of the macro and macronutrient trials were on-farm trials, superimposed upon palms that had been planted by small holders under the replanting programme, at a spacing of $7.32 \mathrm{~m}$ on the triangle. It was therefore possible to select the sites for uniformity from a large number of possibilities. In order to further increase experimental precision recordings were made of various growth and yield parameters before treatment application and this information was used in covariance analysis with posttreatment variates. After the initial analyses of variance and covariance, significance tests were performed using Dunnett's Test in trials in which treatments were being compared with a control, Duncan's New Multiple Range Test where there was no obvious control, and by examining the linear, quadratic ald cubic components of effects in factorial trials, except where there were only two levels, in which case the t-test was used.

Leaf samples were collected pre-treatment and annually thereafter, and analysed for $\mathrm{N}, \mathrm{P}, \mathrm{K}$, $\mathrm{S}, \mathrm{Ca}, \mathrm{Mg}, \mathrm{Na}, \mathrm{Fe}, \mathrm{Mn}, \mathrm{Zn}, \mathrm{Cu}$ and $\mathrm{B}$, and in some cases $\mathrm{SO}_{4}-\mathrm{S}$ and $\mathrm{Cl}$. Wherever possible, leaf samples were collected from the fourteenth frond, but in cases where very unhealthy palms were carrying less than seventeen fronds, the sample was collected from the fourth or fifth frond from the base of the canopy.

In some trials topsoil and subsoil samples were collected pre-treatment and at the conclusion of the trial, and topsoil samples were collected annually. In general, soil samples were analysed for macronutrients, $\mathrm{pH}$ and Cation Exchange Capacity, and in later years phosphorus and trace elements were analysed by the ISFEI Extraction method.

Leaf and soil samples were analysed statistically as well as chemically, and a wealth of information emerged on the inter- relationships between nutrients and their effects upon yield. A full description of this information is beyond the scope of this review, but yield results will be summarised wherever possible.

Local Tall coconuts were used in all case except the Hybrid Coconut Fertilizer Observation (E R 40).

Except for the Basic Nutrition Trial (ER 5), macronutrients were applied as a split dressing, six months apart. Trace elements were applied as a single dose at the beginning of a trial, except that in a few cases treatments were repeated some years later.

Except where iron was a treatment, macronutrient trials were given a basal dressing of ferrous sulphate either by trunk injection or in a single hole in the soil at the base of the trunk, whilst micronutrient trials were given basal dressings of potassium chloride and in some cases nitrogen, as IBDU (Isobutylidenediurea, 32\% N).

\section{MACRONUTRIENTS TRIALS}

\section{E R 23 Nitrogen, Potassium and Placement Trial}

The trial was of $4^{2} \times 2$ factorial design, confounded in incomplete blocks of eight plots in a single replicate, with sample areas of three palms. 
Treatments were:

Nitrogen $\quad-0 ; 593 ; 1,186$ or $1,779 \mathrm{gm} /$ tree/annum IBDU. In the first year the same quantities of nitrogen were applied as ammonium nitrate.

Potassium $\quad-0 ; 500 ; 1,000$ or $15,000 \mathrm{gm} /$ tree/annum potassium chloride.

Placement $\quad-1$ - broadcast, initially within a radius of $1.5 \mathrm{~m}$ from the trunk; from 1985 within $1.0 \mathrm{~m}$ radius.

2 - the same quantity of Fertilizer divided amongst five biodegradable paniphane bags and buried just under the soil surface.

Treatments were initially applied to young non-bearing palms, but yield results were obtained in 1984 and 1985. In 1985 the response to potassium was linear, with the highest level of application yielding $2,776 \mathrm{~kg} / \mathrm{copra} / \mathrm{ha}$, which was 2.4 times that of the zero level. Foliar potassium followed the same pattern. The response to nitrogen was significant but less convincing, with the means following a non-linear pattern, but with the highest level of application yielding 2.1 times that of the zero level, at 3,292 $\mathrm{kg}$ copra/ha (see Table 2). There was some rather unconvincing evidence that placement in biodegradable bags was superior to broadcasting in several variates, but the potassium placement trial gave contradictory results.

Unfortunately this trial was terminated prematurely in 1987 due to discounting of staff.

Table 2. The response to nitrogen and potassium in terms of yield of copra and foliar nitrogen and potassium in the Nitrogen, Potassium and Placement Trial (E R 23), Tuvalu (in 1985)

\begin{tabular}{|l|r|r|r|}
\hline \multirow{2}{*}{$\begin{array}{c}\text { Fertilizer gm/palm/ } \\
\text { annum }\end{array}$} & \multirow{2}{*}{ Yield copra kg/ha } & \multicolumn{2}{|c|}{ Leaf analysis } \\
\cline { 3 - 4 } & & $\mathrm{N} \%$ & $\mathrm{~K} \%$ \\
\hline IBDU & 1,560 & 1.61 & 0.46 \\
0 & 1,578 & 1.50 & 0.47 \\
593 & 1,187 & 1.53 & 0.39 \\
1186 & 3,292 & 1.65 & 0.45 \\
S.e. diff. & 852.4 & 0.0136 & 0.0130 \\
$\mathrm{P}$ & $* 1$ & 0.002 & 0.004 \\
K 1 & & & \\
0 & 1,144 & 1.51 & 0.32 \\
500 & 1,707 & 1.57 & 0.45 \\
1000 & 1,990 & 1.57 & 0.46 \\
1500 & 2,776 & 1.65 & 0.57 \\
S.e. diff. & 852.4 & 0.0145 & 0.0134 \\
P & $* 1$ & 0.004 & $<0.001$ \\
Mean & 1,904 & 1.57 & 0.44 \\
\hline
\end{tabular}

Note:

1. Figure not given in the Annual Technical Report

Treatments were:

Distance - biodegradable bags placed at $50,100,150$ or $200 \mathrm{~cm}$ from the trunk

Number - Fertilizer divided amongst 1, 3 or 6 bags

Controls - 1 - broadcast, initially within a radius of $1.5 \mathrm{~m}$ from the trunk;from 1985 within 1.0 m radius. 2 - no Fertilizer 


\section{E R 24 Potassium Placement Trial}

The trial was of a $4 \times 3+2$ factorial design in two replicates, with sample areas of three palms. Except for the no Fertilizer treatment, all palms received 1,000 gm potassium chloride per annum, in a single application in 1981 and 1982, and split into two in subsequent years.

Treatments were initially applied to young non-bearing palms, but yield results were obtained in 1984 and 1985. The most striking effect to emerge from the trial was the huge response to potassium chloride in the early years of bearing. In 1985 the mean yield of the fertilised plots was 6.5 times that of the untreated control (1,753 vs $269 \mathrm{~kg}$ copra/ha), but variation within the data was huge and the difference was not quite significant $(\mathrm{P}=0.063)$. In 1984 the effect of placement distance was significant and linear $(\mathrm{P}=0.01)$, with yields inversely proportional to distance of placement from the stem. The difference between $50 \mathrm{~cm}$ and $100 \mathrm{~cm}$ was small, but placement at 50 $\mathrm{cm}$ yielded 2.6 times that at $200 \mathrm{~cm}$. In 1985 there was a similar trend in the means but differences were not significant (see Table 3). In the years 1983 to 1986 broadcasting the Fertilizer gave very significantly higher levels of foliar potassium than placement in biodegradable bags $\left(\mathrm{P}^{\prime} \mathrm{s}=0.01\right.$, $0.035,0.001,0.019$ respectively), which contradicts results from the Nitrogen Potassium and Placement Trial (E R 23).

Unfortunately this trial was terminated prematurely in 1987 due to discontinuity of staff.

Table 3. The effect of placement distance in terms of yield of copra in the Potassium Placement Trial (E R 24), Tuvalu

\begin{tabular}{|l|r|r|}
\hline \multirow{2}{*}{ Fertilizer placement distance } & \multicolumn{2}{|c|}{ Yield copra kg/ha } \\
\cline { 2 - 3 } & 1984 & 1985 \\
\hline 50 & 885 & 2,232 \\
100 & 809 & 1,821 \\
150 & 131 & 1,870 \\
200 & 337 & 1,193 \\
S.e. diff. & 213.0 & $* 1$ \\
P & 0.01 & 0.074 \\
\hline
\end{tabular}

Notes:

1. The standard error of difference is not given because the analysis was carried out on transformed data. The means have been detransformed for Table 3.

\section{E R 5 Basic Nutrition Trial, Temaiku Bight}

The trial was initially of a $3^{3}$ confounded factorial design in incomplete blocks of nine plots, with two replicates, and sample areas of four palms. In 1986 the sample areas were split into single tree sub-plots for the trace element treatments. As in other trials, multiple covariance analysis was used to increase precision but in addition a paraboloidal service was used to reduce variation caused by the slope of the land.

Temaiku Bight is an area of reclaimed land consisting of lagoon mud. Unfortunately the site was prone to flooding.

Treatments were:

Nitrogen - IBDU at 0,814 or $1628 \mathrm{gm} / \mathrm{palm} / \mathrm{annum}$. 
Phosphorus - triple superphosphate at $0,1,371$ or 2,742 gm/palm/annum. From 1973-1977 the same quantities of $\mathrm{P}$ were applied as single superphosphate.

Potassium - potassium sulphate at 0,654 or $1,308 \mathrm{gm} / \mathrm{pal} / \mathrm{annum}$.

The rates of application of treatments correspond to $0 ; 123$ and $256 \mathrm{~kg}$ elemental $\mathrm{N}, \mathrm{P}$ and $\mathrm{K}$ per hectare per annum.

Table 4. The effect of method of placement of potassium chloride upon levels of foliar potassium in the Potassium Placement Trial, Tuvalu (E R 24)

\begin{tabular}{|l|r|r|r|r|}
\hline \multirow{2}{*}{$\begin{array}{c}\text { Fertilizer placement } \\
\text { method }\end{array}$} & \multicolumn{4}{|c|}{ \% foliar K } \\
\cline { 2 - 5 } & 1983 & 1984 & \multicolumn{1}{c|}{1985} \\
\hline Bagged & 0.44 & 0.50 & 0.54 & 0.57 \\
Broadcast & 0.62 & 0.64 & 0.75 & 0.75 \\
S.e. diff & 0.0572 & $* 1$ & $* 1$ & 0.0669 \\
P & 0.01 & 0.035 & 0.001 & 0.019 \\
\hline
\end{tabular}

Note:

1. Figure not given in the Annual Technical Report

Trace elements (applied to sub-plots)

0 - nil

1 - 20 gm manganese sulphate per palm

2 - 8 gm zinc sulphate per palm

3 - 3 gm copper sulphate per palm

Trace element sub-treatments were applied by trunk injection (all palms received a basal dressing of ferrous sulphate at $400 \mathrm{gm}$ into the ground at the base of the trunk in 1984, and $27.5 \mathrm{gm}$ by trunk injection in 1986).

There were strong responses to nitrogen and phosphorus in terms of growth parameters, but virtually no crop was ever produced. In several years the application of treatments was prevented by flooding, so in 1986 it was concluded that coconuts could not be grown economically on such a site and the trial was abandoned.

\section{ER 27 N x P x K x 'X' Fertilizer Trial on Marginal Land}

The trial was initially of a $4^{2} \times 2$ confounded factorial design in incomplete blocks of sixteen plots, with two replicates and sample areas of four palms. The design made provision for including an extra factor at two levels (the ' $\mathrm{X}$ ' factor) at a later date, converting the trial into a single replicate.

Treatments were:

Nitrogen - TBDU at $0 ; 1,000 ; 2,000$ or $3,000 \mathrm{gm} / \mathrm{palm} / \mathrm{annum}$.

Phosphorus - triple superphosphate at 0 or $1,000 \mathrm{gm} / \mathrm{palm} / \mathrm{annum}$.

Potassium - potassium chloride at $0 ; 1,000 ; 2,000$ or $3,000 \mathrm{gm} / \mathrm{palm} / \mathrm{annum}$.

In 1991 the ' $\mathrm{X}$ ' factor was used for presence or absence of trace elements, the levels being $12 \mathrm{gm}$ manganese sulphate plus $5 \mathrm{gm}$ copper sulphate (iron having been applied as a basal dressing to all palms). 
The trial was implemented in an area of very poor soil, and the palms were initially very stunted and totally unproductive.

Results showed that where there is a very severe deficiency of potassium palms can be made productive in three years by the application of potassium chloride at $1000 \mathrm{gm} / \mathrm{palm} / \mathrm{annum}$, or in two years by 2000 or $3000 \mathrm{gm} / \mathrm{palm} /$ annum. There was a smaller but significant linear response to nitrogen in the later years. In the early years of production there was a suggestion in the means of a $\mathrm{N} x \mathrm{~K}$ interaction but only in 1992 was the effect significant $(\mathrm{P}=0.006$; linear $\mathrm{x}$ linear component $<0.001$, see Table 5). The yield response to potassium was reflected in foliar potassium, but for some unexplained reason the same was not true of nitrogen. There was no response to phosphorus despite low levels of foliar P. The 'X' factor had not had time to produce effects before the 1990-1992 Technical Report was written.

Table 5. The effect of the nitrogen $x$ potassium interaction upon number of nuts per palm excluding bunches one to four, in the $N \times P \times K \times$ ' $X$ ' Fertilizer Trial on Marginal Land, Kiribati.

\begin{tabular}{|c|c|c|c|c|}
\hline \multirow{2}{*}{$\begin{array}{c}\text { IBDU } \\
\text { (gm/palm/annum) }\end{array}$} & \multicolumn{4}{|c|}{ Potassium chloride (gm/palm/annum) } \\
\hline & 0 & 1,000 & 2,000 & 3,000 \\
\hline 1990 & & & & \\
\hline 0 & 5.1 & 2.2 & 5.7 & 6.5 \\
\hline 1,000 & 8.0 & 8.0 & 6.1 & 11.1 \\
\hline 2,000 & 8.5 & 14.3 & 7.8 & 21.1 \\
\hline 3,000 & 9.1 & 14.1 & 17.5 & 18.4 \\
\hline 1991 & & & & \\
\hline 0 & 4.2 & 17.5 & 7.2 & 14.3 \\
\hline 1,000 & 5.9 & 20.5 & 18.9 & 25.5 \\
\hline 2,000 & 6.9 & 24.1 & 11.7 & 22.8 \\
\hline 3,000 & 10.4 & 20.0 & 19.7 & 32.4 \\
\hline 1992 & & & & \\
\hline 0 & 16.1 & 31.0 & 17.7 & 26.8 \\
\hline 1,000 & 13.5 & 36.4 & 25.0 & 36.7 \\
\hline 2,000 & 23.8 & 39.4 & 38.4 & 44.6 \\
\hline 3,000 & 17.9 & 30.9 & 52.5 & 57.9 \\
\hline
\end{tabular}

\section{E R 34 N x P x K x 'X' x Fe Fertilizer Trial on 'Normal Soil, Kiribati}

The trial was of a $4 \times 2^{3}$ split-plot factorial design confounded in incomplete blocks of eight plots, with an additional factor at two levels applied as a split to each plot. The main factorial structure incorporated an IX' factor which was used in 1991. The trial was initially in two replicates, converted to one replicate when the ' $\mathrm{X}$ ' factor was used up. Whole plot sample areas were of six palms.

Treatments were:

Nitrogen - IBDU at $0,750,1500$ or $2250 \mathrm{gm} / \mathrm{palm} / \mathrm{annum}$.

Phosphorus - triple superphosphate at 0 or $1,000 \mathrm{gm} / \mathrm{palm} / \mathrm{annum}$. 

Potassium - potassium chloride at 0 or $1,000 \mathrm{gm} / \mathrm{palm} / \mathrm{annum}$
'X' factor - presence or absence of 12 gm manganese sulphate plus 5 gm copper sulphate (one application only).
Iron
- ferrous sulphate at 0 or $30 \mathrm{gm} /($ sub-plots) palm, applied by trunk injection In 1986. 'Ferriplex" EDDHA chelate was applied at $34 \mathrm{gm} / \mathrm{palm}$ in separate injection holes in 1988.

The trial was implemented in an area of normal atoll soil. The palms were initially exhibiting symptoms of nitrogen rather than potassium deficiency.

There has been no consistent response to nitrogen, neither in terms of yield nor foliar nitrogen levels, although in some years there have been encouraging trends in the means of yield parameters. This is surprising in view of the low

\section{E R 34 N x P x K x IXI x Fe Fertilizer Trial on 'Normal Soil, Kiribati}

The trial was of a $4 \times 2^{3}$ split-plot factorial design confounded in incomplete blocks of eight plots, with an additional factor at two levels applied as a Bplit to each plot. The main factorial structure incorporated an ' $X$ ' factor which was used in 1991. The trial was initially in two replicates, converted to one replicate when the ' $\mathrm{X}$ ' factor was used up. Whole plot sample areas were of six palms.

Treatments were:

$\begin{array}{lll}\text { Nitrogen } & - & \text { IBDU at } 0,750,1500 \text { or } 2250 \mathrm{gm} / \mathrm{palm} / \mathrm{annum} . \\ \text { Phosphorus } & - & \text { triple } \\ \text { Potassium } & - & \text { potassium chloride at } 0 \text { or } 1000 \mathrm{gm} / \mathrm{palm} / \mathrm{annum} \\ \text { 'X' factor } & - & \begin{array}{l}\text { presence or absence of } 12 \mathrm{gm} \text { manganese sulphate plus } 5 \mathrm{gm} \text { copper } \\ \text { sulphate }(\text { one application } \text { only). }\end{array}\end{array}$

Iron - ferrous sulphate at 0 or $30 \mathrm{gm} /$ (sub-plots) palm, applied by trunk injection in 1986. 'Ferriplex" EDDHA chelate was applied at $34 \mathrm{gm} / \mathrm{palm}$ in separate injection holes in 1988.

The trial was implemented in an area of normal atoll soil. The palms were initially exhibiting symptoms of nitrogen rather than potassium deficiency.

There has been no consistent response to nitrogen, neither in terms of yield nor foliar nitrogen levels, although in some years there have been encouraging trends in the means of yield parameters. This is surprising in view of the low levels of foliar N (mean in $19921.27 \%$ ). There has, however, been a consistent yield response to phosphorus, but the effect is viewed with suspicion because foliar P levels have always been at or above $0.12 \%$. Levels of foliar potassium are higher than in other trials, and although the application of potassium chloride has increased foliar potassium and chloride the yield response has been inconsistent. Levels of foliar iron are very much higher than in other trials (generally around $40 \mathrm{ppm}$ ), and the iron treatment has not affected yields, although due 
to antagonistic reactions the high levels of iron have resulted in very low levels of manganese, zinc and copper, deficiencies of one or more of which may be limiting yields.

\section{E R - N x P x K x ' $X^{\prime}$ x Size of Planting Hole Trial on (Extreme) Marginal Land using Seedlings, Kiribati}

The trial was to have been implemented in an area in which there was no soil as such, the substratum consisting of loose angular stones and rocks, with extensive outcrops of rocky hardpan at the surface, in order to determine whether or not such areas could be made productive, and what inputs would be required. Such sites are not uncommon in Kiribati.

Unfortunately clearance of the site took much longer than anticipated, and at the time there was uncertainty regarding continuity of staff for the supervision of what would obviously be a long-term trial, so it was decided that the trial would not be implemented. It is still felt, however, that such a trial would be valuable, and that it should be implemented when there are resources available to carry it forward to a successful conclusion.

\section{E R 12 Nitrogenous Fertilizer Trial, Kiribati}

The "trial" was meant to compare four sources of nitrogen (calcium ammonium nitrate, urea, ammonium sulphate and IBDU), but due to flawed design to useful information could be obtained. The treatments were superimposed upon a systematic spacing trial, with fertilised plots consisting of three spokes of the spacing trial, separated by control plots of a single spoke, with no discard rows. The palms in the control spokes must have derived considerable benefit from the fertilised palms on either side, especially at the closer spacings, and treatments were not randomised.

\section{E R 40 Hybrid Coconut Fertilizer observation, Kiribati}

This non-statistical observation was intended to obtain preliminary information on the response of Rennell x Local Tall $\mathrm{F} 1$ hybrids growing on marginal soil to Fertilizers. The block of hybrids was divided into four plots and current Fertilizer recommendations were applied to diagonally opposite plots. Unfortunately, although the palm responded visually, no information on yield could be obtained due to theft of nuts, and the observation was discontinued in 1987.

\section{E R 4 Fertilizer observation on Young Palms, Buana Village, Kiritimati, Kiribati}

The observation consisted of just two large plots, one of which was fertilised, at what was for Kiritimati a very favourable site, with a water lens within the rooting zone of the coconut palms. The response to Fertilizer in terms of growth, precocity and yield was impressive, but the experiment will not be described in greater detail here because results are relevant only to the very atypical conditions of the site.

\section{E R 45 Fertilizer observation on Mature Palms, Kiritimati, Kiribati}

This observation was similar to the one described above, but implemented on mature palms at a site typical of conditions on Kiritimati, i.e. very low rainfall, a deep infertile sand, and a water table several metres below the surface. The observation ran for only twenty months, the first year of which was a severe drought, and no response to Fertilizer was observed. Why it was not continued for a longer period is now known. 


\section{MICRONUTRIENT TRIALS}

\section{E R 2 Trace Element Trial, Tuvalu}

The trial was of a randomised blocks design, with four replicates of eleven treatments and single palm plots. The palm selected were stunted, very chlorotic two year old seedlings.

Treatments were:

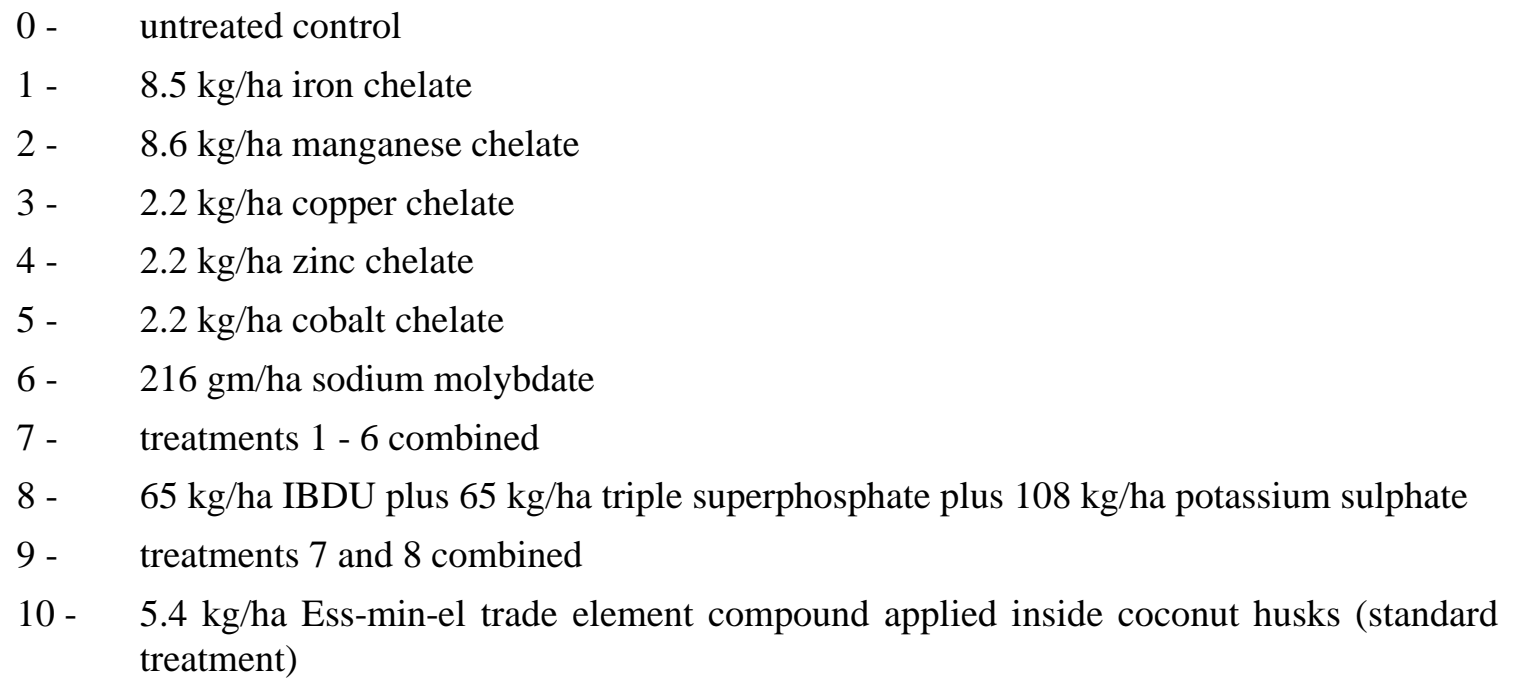

10 - $\quad 5.4 \mathrm{~kg} / \mathrm{ha}$ Ess-min-el trade element compound applied inside coconut husks (standard treatment)

Chelates and sodium molybdate were applied by a combination of foliar spray, into the remains of the husk, and to the soil.

Leaf colour was assessed visually on a $0-8$ scale on four occasions, and measurements were made of the width and length of the longest frond, width of a leaflet in the centre of the longest frond and stem circumference at the base.

All treatments which contained iron responded visually and dramatically within six weeks of treatment application, and this was later reflected significantly in frond length and width, with nonsignificant similar trends in the other variates.

\section{E R 14 Trunk Injection Trial on Young Non-flowering Coconuts, Tuvalu}

\section{E R 15 Trunk Injection Trial on Young Flowering Coconuts, Tuvalu}

These trials were of a randomised blocks design, with single palm plots. E R 14 had three replicates of five treatments (low replication due to a limited number of suitable palms available), whilst E R 15 had four replicates of the same five treatments. The trials were adjacent, so leaf analysis results were analysed as a single trial in seven replicates. The palms selected were about eight years old and looking basically healthy but low yielding.

The following treatments were applied by trunk injection in April 1980:
$0 \quad$ - untreated control
$1 \quad-10 \mathrm{gm}$ ferrous sulphate
2 - 15 gm manganese sulphate
3 - treatments 1 and 2 combined
4 - $\quad 25$ gm Ess-min-el trace element mixture 
In June 1983 treatments were re-applied but with the rates of ferrous sulphate and Ess-min-el increased to $25 \mathrm{gm}$ and $40 \mathrm{gm}$ respectively.

Leaf colour was assessed visually on a $0-5$ scale, pre-treatment and annually thereafter, and there was evidence of an improvement of leaf colour in the three treatments which contained iron. No significant effects emerged from the analyses of yield parameters, but, as in other trials, interesting information on the interrelation- ships between nutrients emerged from the leaf analysis results. These effects are beyond the scope of this review.

\section{E R 20 Levels of Iron Injections into old Coconut Palms, Tuvalu}

The trial was implemented in an area of mature to over-mature coconut palms, irregularly spaced, with six replicates of five treatments in randomised complete blocks, using single palm plots. The area was cleared of dense undergrowth six months before treatment application. Treatments were applied by trunk injection.

Treatments were: $0,10,20,30$ or 40 gm ferrous sulphate per palm, in a single application.

Treatment effects were masked by a massive increase in yield in all treatments following the removal of bush from the site. In the five years of the trial mean yields were respectively 15, 20, 4.4, 10 and 8 times those of pre-treat-ment levels (which were close to zero). The one important conclusion that emerged from the treatments was that $40 \mathrm{gm}$ ferrous sulphate can safely be injected into the trunks of fully mature coconut palms, with no subsequent symptoms of toxicity.

\section{E R 22 Iron Injection Trial with Twelve Year Old Coconuts, Tuvalu}

(This trial has been referred to in previous papers by Trewren (1991/b) and Edwards and Trewren (1992)).

The trial was of a randomised blocks design, with five replicates of six treatments and two adjacent palms per sample area. The palms selected were stunted, very chlorotic, and twelve years old at the start of the trial. The objectives were to compare various methods of application of iron (but see also E R 38, Kiribati), and to determine the optimum level of ferrous sulphate when applied by trunk injection to palms of this age.

Treatments were:

0 - untreated control

$1-10 \mathrm{gm} /$ palm ferrous sulphate by trunk injection

2 - $20 \mathrm{gm} /$ palm ferrous sulphate by trunk injection

3 - $30 \mathrm{gm} /$ palm ferrous sulphate by trunk injection

4 - $37 \mathrm{gm} /$ palm Fe-lo chelate by foliar spray, divided amongst four applications in the first year

5 - four four-inch $(10.2 \mathrm{~cm})$ nails per palm, driven into the trunk

Two years after treatment application it was apparent that the effect of treatment 1 had worn off so palms in that treatment were re-injected with $30 \mathrm{gm}$ of a mixture of sulphates of iron, manganese, zinc and copper in the ratio 70:25:4:1. 
Results indicated that trunk injection of ferrous sulphate at levels up to $30 \mathrm{gm} / \mathrm{palm}$ can safely be applied to palms with trunks two meters or more tall, but there could be some necrosis and rotting of shorter trunks. This level of application was effective for three years, whereas $20 \mathrm{gm}$ would have to be repeated in alternate years. The subsequent application of a trace element mixture to treatment 1 gave erratic results, possibly because the dead tissue lining the original injection hole prevented translocation into the conducting vessels of half of the palms. This was a disappointing conclusion since if a new injection hole has to be drilled every third year the bases of the palms would be seriously weakened by necrotic tissue after several injections.

The foliar application of chelate had a shortlived effect (and would be impractical with tall palms), whilst the nails treatment appeared to have a slight but non-significant effect.

Treatment effects were apparent in terms of a rapid and dramatic visual improvement in leaf colour, followed by larger fronds, an increase in growth rate and foliar analysis results. Three years after treatment application some of the palms came into production, especially in the trunk injection treatments, but despite the fact that the $30 \mathrm{gm}$ trunk injection treatment yielded five to seven times that of the untreated control there were insufficient bearing palms for differences to achieve significance.

Foliar analysis results showed that the application of iron significantly affected levels of nitrogen, phosphorus, sulphur, calcium, magnesium, sodium and manganese. In this trial iron-potassium antagonism was not evident, although that effect did emerge in other trials. The significant effects are summarised in Table 6.

Whilst the inter-relationships between iron and other elements are interesting and fundamentally important on atolls, it is beyond the scope of this review to discuss them here. Results have been briefly discussed in the papers referred to under the heading of the trial.

Table 6. The effects of various method of application of iron on foliar levels of iron, nitrogen, phosphorus, calcium, magnesium, sodium, sulphur and manganese in the Iron Injection Trial with Twelve Year Old Coconuts, Tuvalu.

\begin{tabular}{|c|c|c|c|c|c|c|c|c|}
\hline Treatment & $\begin{array}{l}\text { Fe ppm } \\
\text { at } 4 \\
\text { mounth }\end{array}$ & $\begin{array}{c}\mathrm{N} \% \text { at } \\
6 \\
\text { mounth }\end{array}$ & $\begin{array}{c}\mathrm{P} \% \text { at } \\
16 \\
\text { mounth }\end{array}$ & $\begin{array}{c}\mathrm{Ca} \% \text { at } \\
28 \\
\text { mounth }\end{array}$ & $\begin{array}{c}\mathrm{Mg} \% \text { at } \\
32 \\
\text { mounth }\end{array}$ & $\begin{array}{l}\mathrm{Na} \% \text { at } \\
4 \text { mounth }\end{array}$ & $\begin{array}{c}\mathrm{S} \% \text { at } \\
16 \\
\text { mounth }\end{array}$ & $\begin{array}{l}\text { Mn ppm } \\
\text { at } 16 \\
\text { mounth }\end{array}$ \\
\hline $\begin{array}{l}10 \mathrm{gm} \mathrm{FeSO}_{4} \\
\text { trunk injected }\end{array}$ & 131.4 & 1.62 & 0.17 & 0.50 & 0.50 & 0.58 & 0.16 & 7.5 \\
\hline $\begin{array}{l}20 \mathrm{gm} \mathrm{FeSO}{ }_{4} \\
\text { trunk injected }\end{array}$ & 68.4 & 1.70 & 0.19 & 0.56 & 0.48 & 0.50 & 0.19 & 7.6 \\
\hline $\begin{array}{l}30 \mathrm{gm} \mathrm{FeSO}_{4} \\
\text { trunk injected } \\
\text { Fe-Lo chelate }\end{array}$ & 63.4 & 1.62 & 0.17 & 0.58 & 0.48 & 0.52 & 0.18 & 9.2 \\
\hline $9.25 \mathrm{gm}, 4$ times & 13.2 & 1.24 & 0.15 & 0.64 & 0.63 & 0.77 & 0.14 & 17.1 \\
\hline driven into trunk & 11.8 & 1.26 & 0.15 & 0.61 & 0.51 & 0.71 & 0.14 & 16.5 \\
\hline Untreated control & 9.8 & 1.14 & 0.13 & 0.76 & 0.62 & 0.75 & 0.14 & 19.0 \\
\hline S.e. diff. & 40.08 & 0.0848 & 0.00788 & 0.0711 & 0.059 & 0.0617 & 0.0115 & 2.102 \\
\hline$P$ & 0.05 & $<<0.001$ & 0.001 & 0.05 & 0.05 & 0.001 & 0.001 & 0.001 \\
\hline Mean & 49.7 & 1.43 & 0.16 & 0.61 & 0.54 & 0.64 & 0.16 & 12.8 \\
\hline
\end{tabular}




\section{E R 35 manganese, Zinc and Copper Trial, Kiribati}

The trial was of a 24 factorial design, confounded in incomplete blocks of eight units, with three replicates and three palms per sample area.

Treatments were:

Manganese sulphate $\quad: 0-$ nil $1-20 \mathrm{gm} /$ palm, trunk injected

Zinc sulphate $\quad: 0-$ nil $1-8 \mathrm{gm} /$ palm, trunk injected

Capper sulphate $\quad: 0-$ nil $1-3 \mathrm{gm} /$ palm, trunk injected

NPK

: 0 - nil

1 - 500 gm IBDU, plus 1,500 gm potassium chloride, plus 1,000 gm triple superphosphate per palm per annum.

Trace element treatments were applied in March 1986 and again, in new injection holes, in November 1988. All. palms were given a basal dressing Of ferrous sulphate at $400 \mathrm{gm} / \mathrm{palm}$ in a single hole in the soil at the base of the trunk at the start of the trial.

There have been consistent significant increases in yield in response to the NPK and capper treatments, each producing increases of about $30 \%$. When bath treatments are applied together the means suggest a synergistic effect, more than doubling the yield in some years, but due to plot-to-plot variation the interaction has never been significant (see Table 7). Foliar analysis results suggest that bath potassium and nitrogen are involved in these effects, since the

NPK treatment increases foliar potassium whilst foliar nitrogen is increased by copper. Manganese and zinc have not increased yield but they have produced beneficial effects upon the levels of other nutrients in foliar tissue, so it would be advisable to include them in a trace element mixture for atolls.

\section{E R 36 Trace Element Trial with Young Coconuts, Kiribati}

The trial was of a $2 \times 4(+2)$ factorial design, with four replicates and four palms per sample area. It was the only trial in the programme to be planted from scratch. The site was the most extreme area of iron deficiency that could be found, where there were very few surviving coconuts and all vegetation, including the bush species, was very chlorotic. The objective was to use the information from earlier trials in order to assess the feasibility of giving coconuts a long-term supply of trace elements at the time of planting, and to determine whether or not trace elements other than iron are required.

Table 7. The effects of the NPK $\times$ Cu interaction on number of nuts per palm (excluding bunches one to four, recorded once annually) in the Manganese Zinc and Copper Trial, Kiribati

\begin{tabular}{|c|c|c|c|c|c|c|c|}
\hline & & \multicolumn{2}{|c|}{$1987 \mathrm{Cu}$} & \multicolumn{2}{|c|}{$1988 \mathrm{Cu}$} & \multicolumn{2}{|c|}{$1989 \mathrm{Cu}$} \\
\hline & & 0 & 1 & 0 & 1 & 0 & 1 \\
\hline & 0 & 6.29 & 9.21 & 15.16 & 25.00 & 5.70 & 8.54 \\
\hline \multicolumn{8}{|l|}{ NPK } \\
\hline & 1 & 10.76 & 14.82 & 21.31 & 33.53 & 5.31 & 8.45 \\
\hline
\end{tabular}




\begin{tabular}{|c|c|c|c|c|c|c|c|}
\hline & & \multicolumn{2}{|c|}{$1990 \mathrm{Cu}$} & \multicolumn{2}{|c|}{$1991 \mathrm{Cu}$} & \multicolumn{2}{|c|}{$1992 \mathrm{Cu}$} \\
\hline & & 0 & 1 & 0 & 1 & 0 & 1 \\
\hline & 0 & 4.17 & 2.67 & 17.67 & 21.92 & 15.83 & 28.00 \\
\hline \multicolumn{8}{|l|}{ NPK } \\
\hline & 1 & 2.92 & 5.57 & 26.67 & 40.92 & 23.92 & 38.50 \\
\hline
\end{tabular}

Note: Yields were low in 1989 and 1990 due to drought

Treatments were:

1 - untreated control

2 - 20 flattened iron cans in the planting hole plus $66.7 \mathrm{gm}$ trace element mix applied in the husk.

3 - $50 \mathrm{gm}$ ferrous sulphate applied in the husk at the time of planting.

4 - $66.7 \mathrm{gm}$ trace element mixture applied in the husk at the time of planting

5 - treatment 3 plus 375 gm ferrous sulphate inside a husk buried next to the seedling

7 - treatment 3 plus 375 gm ferrous sulphate inside a biodegradable bag which is itself placed inside a husk, buried next to be seedling.

9 - treatment 3 plus 375 gm ferrous sulphate inside a punctured iron can buried next to the seedling.

Treatments 6,8 and 10 were similar to treatments 5,7 and 9, but a trace element mixture was used instead of ferrous sulphate ( $66.7 \mathrm{gm}$ into the husk and $500 \mathrm{gm}$ by the other methods, so that treatments 5 to 10 all received the same quantity of ferrous sulphate). The trace element mixture consisted of sulphates of iron, manganese, zinc and copper in the ratio 75:15:7:3.

A wealth of significant effects emerged from the initial growth and foliar analysis results and preliminary yield results were obtained in 1992, six years after planting (see Table 8) The most important conclusion to be drawn from the trial is that with the addition of trace elements even such an extreme site can be made productive. The superiority of all treatments over the control plots is apparent in all growth and yield, and most foliar analysis variates. The notable exception is the significantly higher levels of foliar potassium in the control plots due to iron-potassium antagonism in the treatments. The yield results give a strong indication that the trace element mix is superior to ferrous sulphate alone, but at this stage all treatments contain one or more plots which have not yet come into production, and differences are not statistically significant. Despite this, the means have been presented in Table 8 because in practical terms differences are too great, and the inferences too important, to be ignored.

The application of trace elements to the husk at the time of planting was effective for four years but the superiority of the treatments which have received extra trace elements in the planting hole is now apparent. The application of extra trace elements inside a biodegradable bag inside a husk has been inferior to other methods of application in several respects, and, at best, it can be said that there is no advantage to be gained by the use of the biodegradable bags. The addition of iron cans to the planting hole has given encouraging results in terms of foliar zinc and yield.

These results indicate that when planting coconuts on atolls, iron cans should be put into the planting hole, $50 \mathrm{gm}$ trace element mix should be put into the husk of the seedling at the of planting (see E R 31 levels of Trace Element Application of Coconut Seedlings, Kiribati); this application will be effectIve for four years, at which time $200 \mathrm{gm}$ trace element mixture (see E R 37, the Levels of Trace Elements Trial, below) should be buried next to each palm, either in a punctured iron can or inside a coconut husk.

The trial is continuing for a few more years. 
Table 8. The effects of treatments on the number of nuts per palm, (excluding bunches one to four, recorded once annually) in the Trace Element Trial with Young Coconuts, Kiribati in 1992

\begin{tabular}{|l|c|c|}
\hline & \multicolumn{2}{|c|}{ No. nuts/palm } \\
\hline No extra (in seedling husk) & Feso ${ }^{4}$ only & T/E mixture \\
Extra in buried husk & 2.00 & 3.00 \\
Bio-bag in buried husk & 3.00 & 17.75 \\
Extra in can & 3.00 & 10.50 \\
Fe vs T/E mean & 6.00 & 15.00 \\
T/E plus cans in hole & 3.50 & 11.56 \\
Control & & 27.00 \\
\hline
\end{tabular}

\section{E R 37 Levels of Trace Elements Trial, Kiribati}

The trial was of a split-plot design, with five main treatments and three sub-treatments in three replicates and six palms per whole plot sample area. There was an additional replicate in an adjacent area in which palms were so stunted due to iron deficiency that after seven years of growth those that had survived were no larger than newly planted seedlings. This replicate was for observational purposes only, and treatments were applied to it at half quantities.

Treatments were:

Main treatments:

$0,100,200,300$ or $400 \mathrm{gm}$ trace element mixture per palm.

sub-plot treatments:

1 - buried in a hole next to the trunk

2 - in a biodegradable bag buried next to the trunk

3 - half applied into a hole and half in a punctured iron can buried next to the trunk

The trace element mixture consisted of sulphates of iron, manganese, zinc and copper in the ratio $75: 15: 7: 3$.

Although the palms were seven years old at the start of the trial, they were stunted and chlorotic and first yield results were not obtained until the year of its conclusion in 1991. By this time treatment effects had worn off and there were no significant differences. Foliar analysis and growth results indicated that there was no advantage to be gained from the application of more than $200 \mathrm{gm}$ trace treatments, in terms of the initial response and length of the residual effect, which was three years. As with E R 36, the use of biodegradable bags proved inferior to other methods of application, and there were indications that the use of cans was better than applying the trace 
element mixture into the soil. The manganese in the mixture was rapidly assimilated, whereas levels of foliar copper remained low, suggesting that the proportion of copper in the mixture should be raised at the expense of manganese, and possibly zinc also.

\section{E R 38 Iron Application Trial, Kiribati}

The trial was of a randomised blocks design with four replicates of twelve treatments and two palms per sample area.

Treatments were:

0 - untreated control

1 - 30 gm ferrous sulphate injected into the trunk;

2 - 400 gm ferrous sulphate buried in one hole near the trunk;

3 - 400 gm ferrous sulphate buried in a biodegradable bag near the trunk;

4 - 400 gm ferrous sulphate buried in a punctured iron can near the trunk;

5 - $30 \mathrm{gm}$ ferrous sulphate injected into the trunk inside a biodegradable bag;

6 - 100 gm Fe-hi chelate sprayed over the soil then dug in;

7 - 85.7 gm Fe-lo chelate injected into the trunk;

8 - 100 gm Fe-hi chelate buried next to the trunk in a biodegradable bag;

9 - 100 gm fritted iron applied to the soil then dug in;

10 - $30 \mathrm{gm}$ fritted iron injected into the trunk;

11 - 100 gm iron filings injected into the trunk.

The site chosen for this trial was one in which virtually all of the palms were chlorotic but had formed trunks (which was necessary since some of the treatments involved trunk injection).

The chelates produced a very rapid effect in terms of foliar iron and leaf colour (within six months) whereas the sulphate treatments were a little slower but also very effective. The effect of the chelates was short lived (two years), whereas the sulphate treatments remained effective for three to four years. Fritted iron did not produce a noticeable effect until two and a half years after treatment, but the two fritted treatments were the only ones still showing a residual effect in terms of foliar iron at the conclusion of the trial five and a half years after initial treatment application. Iron fillings produced only a slight effect. There was little to choose between soil application and trunk injection in terms of foliar iron, but trunk injection involves the use of much smaller quantities of chemical, although this method cannot be used repeatedly due to the damage to the trunk caused by necrosis around the injection hole.

As in E R 36 and E R 37, there was no advantage to be gained from the use of biodegradable bags, but the cans treatment was effective.

Initial yield results were obtained in 1991 but variation was too great to achieve significant effects. It was noticeable, however, that all treatments except the soil application of chelate and trunk injection of iron filings produced more than twice as many nuts as the untreated control, and the two fritted iron treatments being the highest yielding ( 35.75 and 34.25 nuts/palm as opposed to 4.00 nuts/palm in the control. 
The overall conclusion was that the most effective method of giving a long-term correction of iron deficiency in mature palms would be a trunk injection of iron chelate plus a soil application of fritted iron. However, both of these chemicals are expensive, and a much cheaper and only slightly less effective alternative would be a trunk injection of ferrous sulphate followed by $200 \mathrm{gm}$ ferrous sulphate inside a punctured iron can or coconut husk buried next to the trunk three years later (see E RIS 36 and 37).

\section{E R's..........Trace element Trials, Kiritimati, Kiribati}

See Note 4 under Table 1.

\section{NURSERY TRIALS}

\section{E R 17 Fertilizer Placement Trial on Coconut Seedlings, Tuvalu}

The trial was a $2^{7}$ factorial, confounded in incomplete blocks of eight plots, in half a replicate, with four seedlings per plot.

Treatments one to six were presence or absence of:

$\begin{array}{ll}\text { Nitrogen } & -60 \mathrm{gm} \text { IBDU per seedling } \\ \text { Potassium } & -60 \mathrm{gm} \text { potassium chloride per seedling } \\ \text { Sulphur } & -30 \mathrm{gm} \text { flowers of sulphur per seedling } \\ \text { Copper } & -2 \mathrm{gm} \text { copper oxychloride per seedling } \\ \text { Manganese } & -15 \mathrm{gm} \text { manganese sulphate per seedling } \\ \text { Iron } & -10 \mathrm{gm} \text { ferrous sulphate per seedling }\end{array}$

Treatment 7 was:

0 - nutrients sprinkled over the soil surface then lightly forked and watered in

1 - nutrients added in a biodegradable paniphane bag, one per seedling.

Seedlings were pre-germinated then transplanted into polybags, at which time treatments were applied and growth variates were recorded for subsequent use as covariates.

The application of nitrogen significantly REDUCED number of $\mathrm{f}$ ronds per plant $(\mathrm{P}<0.05)$ , whereas potassium significantly increased height of shoot $(\mathrm{P}$ almost 0.001$)$. The nitrogen effect was due to a significant increase in leaf fungal diseases in the nitrogen treatment $(\mathrm{P}<0.01)$, especially when the Fertilizer was broadcast ( $\mathrm{N}$ x methods interaction $\mathrm{P}<0.05)$. It could be that the trial was of too short a duration for the nutrients to be released from the biodegradable bags. This theory is supported by significant $\mathrm{N} x$ methods and $\mathrm{K}$ x methods interactions on shoot height, which indicated that the positive effect of potassium and the negative effect of nitrogen occurred only when the Fertilizer was broadcast. There were several other significant interactions (on shoot height, Fe $\mathrm{x}$ $\mathrm{S}$ and $\mathrm{N} \times \mathrm{Mn} \times \mathrm{Fe}$; on shoot girth, $\mathrm{N} \times \mathrm{S}$ and $\mathrm{S} \times$ methods; on leaf fungal disease, Fe x S and $\mathrm{S} \times$ methods) which were difficult to explain in the light of information from other trials, and seem best treated with suspicion until results are clarified by further research. 


\section{E R 16 (A) Trace Element Trial on Coconut Seedlings, Tuvalu}

\section{E R 30 Trace Element Trial on Coconut Seedlings, Kiribati}

These trials were of randomised blocks design, with four replicates of fourteen treatments, and four seedlings per plot. E R 16(A) in Tuvalu utilised seedlings grown in nursery beds, and included a guard row of seedlings around each plot, whereas E R 30 in Kiribati utilised polybags and there were no guard rows.

Treatments were:

$0 \quad$ - untreated control;

$1 \quad-10$ gm Fe-hi chelate per plant;

$2 \quad-12 \mathrm{gm} \mathrm{Mn}$ chelate per plant;

$3 \quad-3 \mathrm{gm} \mathrm{Cu}$ chelate per plant;

$4 \quad$ - 3 gm Co chelate per plant;

$5 \quad-12 \mathrm{gm} \mathrm{Mg}$ chelate per plant;

$6 \quad-3$ gm Zn chelate per plant;

$7 \quad-0.5 \mathrm{gm}$ sodium molybdate per plant;

$8 \quad-30$ gm flowers of sulphur per plant;

$9 \quad-30$ gm borax per plant;

10 - treatments 1-9 combined, all applied to the soil;

$11-30$ gm triple superphosphate plus $60 \mathrm{gm}$ potassium chloride per plant;

12 - treatments 10 and 11 combined;

$13-25 \mathrm{gm}$ standard trace element mixture per plant, applied inside the husk.

In E R 16(A) treatments 1 to 7 were applied into a hole cut into the husk of the germinated seedling. Other treatments in E R 16 (A), and treatments 1 to 12 in E R 30 were applied to the soil.

Treatment 13 was the standard treatment at the time, the trace element mixture consisting of sulphates of iron, manganese, zinc and copper in the ratio 70:25:4:1.

Number of fronds per plant, shoot height and shoot girth were recorded pre-treatment and five months later. There were no significant effects in either trial (despite very low standard errors), although in E R 30 the means suggested that treatment 13 may have had a slightly toxic effect when applied to young seedlings (see also E R 31).

\section{E R 67 Trace Element Placement Trial on Coconut Seedlings, Tuvalu}

\section{E R 32 Trace Element Placement Trial on Coconut Seedlings, Kiribati}

These trials were of randomised blocks design, with five replicates of seven treatments, and four seedlings per sample area. E R 67 in Tuvalu utilised seedlings grown in nursery beds, and included a guard row of seedlings around each plot, whereas E R 32 in Kiribati utilised polybags and there were no guard rows. 
Treatments were:

0 - untreated control;

$1-70 \mathrm{gm}$ trace element mixture per plant, applied to the soil;

2 - 20 gm trace element mixture per plant, applied to the soil;

$3-20 \mathrm{gm}$ trace element mixture per plant, in a biodegradable bag buried next to the seedling;

4 - 20 gm trace element mixture in a hole in the husk of the seednut, with the plug then replaced;

5 - $20 \mathrm{gm}$ trace element mixture in a biodegradable bag placed in a hole in the husk of the seednut, with the plug then replaced;

6 - chelated trace elements (10 gm Fe +12 gm $\mathrm{Mn}+3 \mathrm{gm} \mathrm{Zn}+3 \mathrm{gm} \mathrm{Cu})$ sprayed over the soil surface then dug in.

The trace element mixture consisted of sulphates of iron, manganese, zinc and copper in the ratio 70:25:4:1.

There were no significant effects in the trial in Kiribati, but in Tuvalu, where the seedlings had been older at the time of treatment application, the two treatments in which trace elements were applied into the husk were significantly better than untreated control $(\mathrm{P}<0.05)$ in terms of shoot girth. The application of trace elements to the soil had no effect, whatever the method of application, or whether sulphates or chelates were used.

\section{E R 68 Levels Of Trace Element Application to Coconut Seedlings, Tuvalu}

\section{E R 31 Levels Of Trace Element Application to Coconut Seedlings, Kiribati}

These trials were of randomised blocks design, with six replicates of six treatments, and four seedlings per plot. E R 68 in Tuvalu utilised seedlings grown in nursery beds, whereas E R 31 in Kiribati utilised polybags. There were no guard rows in either trial.

Treatments were:

$0,15,30,45,60$ or $75 \mathrm{gm}$ trace element mixture per plant, with all treatments being applied to a hole cut into the husk of the seedling, as far away from the shoot as was possible.

An important difference between the trials was that in Tuvalu treatments were applied to seedlings which had germinated four months previously whereas in Kiribati much younger seedlings were used, having shoots 24 to $32 \mathrm{~cm}$ tall with no true fronds developing (and therefore in this trial pre-treatment number of fronds could not be used as a covariate).

In addition to the normal growth variates toxicity symptoms were assessed on a 0 to 6 scale.

In Kiribati there was a significant inverse relationship between levels of application and all growth variates. In Tuvalu differences were not significant although the means suggested an optimum level of about $45 \mathrm{gm} / \mathrm{palm}$. There were no obvious symptoms of toxicity in either trial, but the seedlings in the control plots were noticeably paler than those which received treatments. The obvious inference is that trace elements must not be applied to young germinated seednuts, but at the time of planting out (four leaf stage or older) $50 \mathrm{gm} /$ plant can be applied into the husk. 
Table 9. The effects of treatments upon growth parameters in the Levels of Trace Element Application to Coconut Seedlings Trials, Tuvalu and Kiribati

\begin{tabular}{|l|c|c|c|c|c|c|}
\hline \multirow{2}{*}{$\begin{array}{c}\text { Trace element } \\
\text { level }\end{array}$} & \multicolumn{4}{|c|}{ Tuvalu } & \multicolumn{3}{|c|}{ Kiribati } \\
\cline { 2 - 7 } & $\begin{array}{c}\text { No. fronds per } \\
\text { plant }\end{array}$ & $\begin{array}{c}\text { Shoot height, } \\
\mathrm{cm}\end{array}$ & $\begin{array}{c}\text { Shoot girth, } \\
\mathrm{cm}\end{array}$ & $\begin{array}{c}\text { No. fronds per } \\
\text { plant }\end{array}$ & $\begin{array}{c}\text { Shoot height, } \\
\mathrm{cm}\end{array}$ & $\begin{array}{c}\text { Shoot girth, } \\
\mathrm{cm}\end{array}$ \\
\hline 0 & 7.2 & 147 & 13.7 & 5.7 & 123.5 & 12.8 \\
15 & 7.3 & 138 & 13.7 & 5.5 & 112.5 & 12.1 \\
30 & 7.5 & 140 & 13.6 & 5.2 & 105.8 & 11.2 \\
45 & 7.5 & 145 & 13.7 & 5.0 & 97.9 & 10.8 \\
60 & 7.1 & 139 & 13.2 & 4.9 & 93.5 & 10.7 \\
75 & 6.8 & 140 & 13.2 & 4.3 & 90.1 & 9.7 \\
& & & & & & \\
S.e. dif & 0.297 & 7.81 & 0.482 & 0.259 & 6.25 & 0.462 \\
P & $\mathrm{ns}$ & $\mathrm{ns}$ & $\mathrm{ns}$ & 0.05 & 0.01 & 0.01 \\
Mean & 7.2 & 142 & 13.5 & 5.1 & 103.9 & 11.2 \\
\hline
\end{tabular}

Note:

N.s. - Not significant

\section{E R .... Coconut Nursery Disease Control Trial, Tuvalu}

This trial was to investigate the effect of shade netting, sea water and Benlate sprays upon the incidence of leaf fungal disease caused by Drechslera incurvata. Unfortunately the seedlings were somewhat over-aged at the time of treatment application and all plots had a high incidence of disease, resulting in inconclusive results.

\section{OTHER TRIALS}

\section{E R 25 An Evaluation of Coconut Wood Ash as Fertilizer and Coconut Charcoal to Improve the Moisture Retention of Coralline Soil, Tuvalu}

This trial investigated the use of coconut products as Fertilizer rather than the addition of Fertilizer to coconuts. In addition to the 1981 Annual Report, results have been published (Trewren, 1985/b, 1986/d).

\section{CONCLUSIONS AND RECOMMENDATIONS}

Recommendations on the manuring of coconuts grown on atolls can now be given with some confidence, both for new plantings and the rehabilitation of existing stands, even where nutritional problems are very severe.

In the nursery, seedlings will benefit from the application of potassium chloride. In E R 17 the level applied was $60 \mathrm{gm}$ per seedling, but there has been no subsequent work to determine the optimum level. Nitrogen should NOT be applied.

Planting holes should be dug about $60 \mathrm{~cm}$ cube to facilitate the incorporation of husks, other organic matter and twenty flattened iron cans (see E R 36). 
Seedlings should be transplanted from the nursery at the four to five leaf stage (see E R 31). At this stage a hole should be cut into the husk well away from the shoot, and 50 gm trace element mixture is poured into the hole (see E R's 68 and 31), and the plug is replaced after removing some of the fibres f rom the inside so that it fits. If seedlings have been grown in nursery beds it is better to apply the trace elements before lifting the seedlings, otherwise their roots will be badly damaged by the operation of cutting the hole in the husk.

The trace element mixture should consist of: (see E R 37).

$78 \%$ iron sulphate

$12 \%$ manganese sulphate

$5 \%$ zinc sulphate

$5 \%$ copper sulphate

This application will be effective for four years (see E R 36).

During the first year the seedlings should be given $50 \mathrm{gm}$ potassium chloride every three months, increasing the application rate by $50 \mathrm{~g}$, every twelve months, until by the fifth year each palm receives $1000 \mathrm{gm}$ per annum. The application rate should be maintained at this level in subsequent years (see ER's 23 and 27). The Fertilizer should be broadcast within a radius of one metre from the trunk, even for bearing palms (see E R 24).

For the rehabilitation of mature palms 30 gm trace element mixture may be applied by trunk injection to palms which have a trunk at least two metres tall. This will be effective for three years (see E R 22). For palms which have a trunk less than two metres tall (including young plants which were not given trace elements at the time of planting), and for subsequent applications of trace elements to palms which received a trunk injection three years earlier, $200 \mathrm{gm}$ trace elements may be applied either in an iron can which has been punctured using a nail, with the lid being replaced on top of the trace elements, or inside a coconut husk (both halves, after removing the shell). The can or husk should be buried just under the soil surface adjacent to the trunk. This application will be effective for four years (see E R's 36 and 37).

In addition to the trace elements potassium chloride should be applied at 1,000 $\mathrm{gm} / \mathrm{palm} / \mathrm{annum}$, preferably split into four applications of $250 \mathrm{gm}$. Palms which are severely deficient can be brought into production in three years using this level, and yields will continue to rise in subsequent years in proportion to levels of foliar potassium (with little or no crop at foliar potassium levels below $0.3 \%$ ). Palms may be brought into production in two years by using 2,000 or $3000 \mathrm{gm} \mathrm{KC1/palm}$ annum but it is doubtful whether these rates would give an economic return (see E R's 23 and 27).

Levels of foliar potassium have been depressed by the application of iron in several trials (e.g. E R 36), by manganese and possibly copper in E R 35, but raised by zinc in E R 35 .

A positive response to nitrogen was obtained in ER's 23 and 27, and in E R 27 there was a synergistic effect between nitrogen and potassium. Unfortunately, however, the source of nitrogen used in these trials (IBDU) is prohibitively expensive. Potassium nitrate would be the obvious choice of Fertilizer but there is concern over the possible effect of a nitrate Fertilizer on the water lens. It is surprising that the application of IBDU has not significantly raised levels of foliar nitrogen in three trials, despite the positive yield responses obtained, and the fact that foliar nitrogen has been raised by iron in several trials, and by copper and possibly manganese in E R 35 . There was a positive synergistic effect on yield between copper and the NPK treatment in E R 35, and since copper 
significantly raised levels of nitrogen, it is assumed that it was the N within the NPK treatment which interacted with copper.

Further research is needed to identify a less expensive source of nitrogen; on the effect of Fertilizers containing nitrates on the level of nitrates in the water lens (in comparison with the level of nitrates in the traditional system of cultivating giant swamp taro (Cyrtosperma chamissionis) and taro (Colocasia esculenta) in heavily mulched pits dug to the water lens) - Less important topics for research would be the determination of the optimum level of application of potassium chloride to seedlings in the nursery, and optimum frequency of application of potassium chloride in the field (all treatments receiving the same quantity).

\section{ACKNOWLEDGEMENTS}

The author is deeply indebted to Mr. J. J. F. Barr for permission to use the information from this Technical Report on Coconut Research in Kiribati, 1990-1992 (Barr 1992), and for carrying the trials forward to- a successful conclusion. The recent information and conclusions from E R's 27, 34, $35,36,37$ and 38 have been drawn from his report.

\section{REFERENCES}

(See Table 1 in addition to the text)

Barr, J J F (1992) Technical Report on Coconut Research in Kiribati 1990-1992. Ministry of the Environment and Natural Resources Development, Division of Agriculture.

Edwards, S \& Trewren, K (1992) Coconut production on coral atolls. A Review of Agricultural Development in the Atolls. Agricultural Research Programmes for Atolls, Pacific Harbour, Fiji, November 1990.

Fremond, Y (1958) Coconut in Polynesia. Development Prospects. Oleagineux No.6, June 1958.

Fremond, Y (1961) Amelioration de la culture du cocotier sur les atolls du Pacifique tropicale. $10^{\text {th }}$ Pacific Congress, Symposium on Tropical Crops Improvement, 1961.

Jenkin, R N \& Foale, M A (1968) An Investigation of the Coconut Growing Potential of Christmas Island, Land Resources Division, Directorate of Overseas Surveys, United Kingdom.

Manciot, R (1967) Utilisation du diagnostic foliaire dans la mise en place d'un reseau experimental. SPC Technical Conference on Coconut Production, Rangirca, 1967.

Meadows, D J (1961) Coconut grove improvement in the Gilbert and Ellice Islands, with reference to the application of the results of the IRHO research. Oleagineux, $19^{\text {th }}$ year, No. 11, 1961.

Pomier, M (1964) Restauration et nutrition des cocoteraies etablis sur sol corallien. Oleagineux $19^{\text {th }}$ year, No. 10, 1964.

Pomier, M (1967/a) Coconut Research at Rangiroa. SPC Technical Paper No. 153.

Pomier, M (1967/b) Nucrition en oligo-elements des jeunes cocotiers planters sur sol corrallien. SPC Technical Conference on Coconut Production, Rangiroa, 1967. 
Fomier, M (1969) Nutrition minerale des jeunes cocatiers sur sols coralliens. Oleagineux, 24 (1)

Reboul,J L (1980) Coconut growing on coral soil: Evaluation of technical results from experimental work carried out at Rangiroa since 1959. Regional Technical Meeting on Atoll Cultivation, Papeete. SPC Technical Paper No.180.

Reboul, J L (1982) Mission GERDAT-IRAT. Travaux d'experimentation 1982. Rapport de synthese.

Trewren, K (Ed) (1981/a) Tuvalu, Ministry of Commerce and Natural Resources, Department of Agriculture, Annual Report, 1980, Detailed Version.

Trewren, K (Ed) (1981/b) Tuvalu, Ministry of Commerce and Natural Resources, Department of Agriculture, Annual Report, 1981.

Trewren, K (Ed) (1982) Tuvalu, Ministry of Commerce and natural Resources, Department of Agriculture, Annual Report, 1982.

Trewren, K (1983) The Development of the Coconut Resource of Kiribati, Revised Edition. Ministry of Natural Resources Development, Division of Agriculture.

Trewren, K (1985/a) Crop Research in Kiribati, 19821984. Ministry of Natural Resources Development, Division of Agriculture.

Trewren, K (1985/b) A note on charcoal - a promising additive to Fertilizer with particular relevance to coralline soils. Alafua Agricultural Bulletin, 101, April, 1985.

Trewren, K (1986/b) Annual Technical Report on Crop Research in Kiribati, 1985. Ministry of Natural Resources Development, Division of Agriculture.

Trewren, K (1986/c) Annual Technical Report on Crop Research in Kiribati, 1986. Ministry of Natural Resources Development, Division of Agriculture.

Trewren, K (1986/d) Charcoal - a useful additive to Fertilizer for coral soils. An experiment in Tuvalu. Harvest 12 1, 1986.

Trewren, K (1987) Tuvalu, Ministry of Commerce and Natural Resource, Development of Agriculture, Technical Report on Tree Crops Research, 1986.

Trewren, K (1991/a) Tuvalu, Ministry of Commerce and Natural Resources, Department of Agriculture, Technical Report on Tree Crops Research, 1987.

Trewren, K (1991/b) Coconut Production on Coral Atolls. World Bank Technical Paper Number 136. Coconut Production. Present Status and Priorities for Research (Alan H Green, Editor). 